\section{CANADA'S TO-MORROW}

T

HE Canadian Westinghouse Co., Ltd., believes that "business and industry can flourish only as the whole nation advances in the direction of the good life", and a few months ago expressed its appreciation of fifty years spent in Canada in a rather unusual way-by the sponsoring of a conference at Quebec for the study of the country's future. The papers read at the conference provided an excellent picture of Canada's past and present, and also gave some glimpse of the future. "A sober, calm, highly critical assessment" was the description of one of the guests, who remarked on the lack of that complacency which might so easily have resulted from the sudden upsurge in the country's fortunes. Canadians of the calibre of the eight conforence speakers clearly have a very realistic grasp both of Canada's internal situation and of the part that her people must play in the troubled world of to-day.

Canada's resources are both human and natural. B. K. Sandwell discussed the people, whose numbers, he is convinced, could be greatly increased without adversely affecting the present high standard of living, so great are the country's resources and so vast the potential market for primary and secondary products, both within Canada and in the United States and elsewhere. The natural resources were discussed in a comprehensive stocktaking by Maxwell W. Mackenzie. $\mathrm{He}$ stressed in particular the suitability of the timber of the Canadian shield for newsprint, the value of the mineral resources of the shield and other areas, and the significance of the fact that hydro-electricity can easily be transmitted to the points where energy is required. He believes that the time has come for electricity, gas and oil to be distributed through a national network, since their part in Canada's future must be at least as great as has been the contribution of rail, road and water transport in the past. He also emphasized the importance of conservation practices and research programmes, especially for timber and cereals, which together accounted for 45 per cent of the value of Canada's exports in 1951. Food production, apart from wheat, should, he suggested, be based on probable domestic demand. The United States and other countries should still be permitted to purchase primary products such as timber, though at the same time Canada must press for the reduction of trade barriers, especially those which prevent the export of processed products such as plywood and composition boards. She must also be courageous in her attitude towards, and exploitation of, her extensive resources. He sees no justification for the hoarding of the nation's very considerable wealth of copper, lead, zinc, nickel, cobalt, tungsten, iron ore, titanium and other lesser known but important alloy metals, or for placing restrictions upon the export of primary products. The mining of the iron ore of Labrador and of lead and zinc at Pine Point on Great Slave Lake, for example, would undoubtedly result in the opening-up of vast new stretches of country.

These great resources, while providing Canadians with considerable material comfort and higher standards of living, also help to give rise to what $R$. K. Stratford, scientific adviser of Imperial Oil, Ltd., called "the greatest social challenge in history". Several of the papers dealt with the impact of economic development upon the social and political life of the community, through education, industry and government. It was recognized that "we refuse to give to our hearts and minds the thought and care that we lavish on our physical needs", and that far more attention is commonly directed to the problems of industry and resources than to the study of urban and rural social problems. One speaker pleaded for the expansion of university departments, whence might come "long, systematic studies of the human being under different environmental conditions". Another deplored the gap between the two main cultures, the French and the English, and advocated the erection of bridges across the cultural gulf : this, she believed, might be achieved by an increasing sense of the need, "not for a superficial and chatty bilingualism, but for a genuine mastery of the two languages". Realistic recognition was also given to the third great cultural force, that of Canada's neighbour, the United States. Faced with these various influences and traditions, there should be encouraged in Canadian schools "individual selfreliance in opinion, critical dissidence, intelligent nonconformity, the ability at least occasionally to stand aside and stand up for one's own individual beliefs".

The role of government, in economic and social affairs, has changed considerably during recent years. Government encouragement of economic activity, as in the building of communications and the fostering of settlement, has given way to private enterprise, and public authorities are now increasingly concerned with social security and short-term economic stability. Prof. Maurice Lamontagne, of Laval University, claimed that the Canada of the future needs neither capitalism nor socialism but a complementary relationship between private initiative and government action, with the Federal Government playing a dominant part in the collective effort to maintain economic equilibrium.

Prof. D. G. Creighton, professor of history in the University of 'Toronto, turned the thoughts of the conference to Canada's place in the world. The country has already established her independence within North America and a prominent place in the Commonwealth, and is rapidly sccuring for herself an acknowledged position in international affairs. She has, in his view, to accept a world in which Communism dominates the larger part of Asia,' and must be prepared to abandon what he called "our complacent, parochial North Americanism". It is essential that Canada should give to the United Nations its steady support.

At the close of the conference Prof. D. W. Brogan, as "an outsider looking in", surveyed the wide range of papers and subjects discussed. He said he was impressed by the wealth of Canada's resources, but he saw "the basic source of Canadian prosperity in the character of the Canadians and of their civilization". Canada has shown the world that the highest potentialities of modern technology are attainable without violence, disorder, or cultural savagery. As population increases - as it should-by natural increase and by immigration, the specifically Canadian aspects of North American culture must be fostered and the double culture of Canada steadily fused. Each group must express its own vision of Canadian life, at the same time sharing that vision with its neighbour. Canada, Prof. Brogan reminded his listeners, "is the heir of the two great formative traditions of western Europe: it is her pride and opportunity to develop both".

Canada's to-morrow is'bright and promising because Canadians are proud of her past and conscious of the opportunities of the present. Through the public spirit of a great concern-typical of many of the corporations of North America-and because of its 
confidence in the nation's future, more than three, hundred representatives of Canada's commercial, industrial and cultural life were able to share in the thoughts and concerns of a few of their fellow-country. men through this conference.

The papers form an invaluable commentary on Canadian thinking to-day, and on Canada's prospects to-morrow. Fortunately, the Canadian Westinghouse Co. has now published the papers in book form*, thus making available for a much wider audience the deliberations of this very balanced and comprehensive conference. ROBERT W. STEET

* Published by the Macmillan Co. of Canada, Lta, 70 Bond strect" 'Joronto. 3.50 dollars.

\section{THE SPORTS TURF RESEARCH INSTITUTE \\ SILVER JUBILEE}

$\mathrm{T}$ O mark the silver jubilee of the Sports 'Turf Research Institute, a conforenco and open day were held at its headquarters, St. Ives Research Station, Bingley, Yorkshire, on July I. A most satisfactory attendance, including representatives from sports clubs, sports associations, education authorities and municipalities throughout the British Isles, was presented with a very full day's programme in which major items were exporiment plot demonstrations, educational exhibits, displays of modern machinery and the presentation of various papers on turf topics at intervals during the day.

The director of the Institute, Mr. R. B. Dawson, spoke about the developments of scientific turf management during the past twenty-five years, stressing particularly the big improvements in design and range of equipment that have taken place. $\mathrm{He}$ referred also to the growth of the experimental and other work of the Research Station. Mr. J. R. Escritt (soil chemist) discussed the relativo importance of physical and chemical properties of soils for turf production, and Mr. J. Drew Smith (plant pathologist) dealt with turf diseases and his own work on fungicides. The fourth paper, given by Mr. G. Wright, a member of the Board of Management, described turf research work in progress at several research centres in the United States, emphasizing the big problems created in somo parts by climatic factors adverse to good turf production.

The Institute (formerly known as the Board of Greenkeoping Research) has the stated aim of raising the general standard of sports turf. It is supported by subscriptions from numerous interested bodies, including sports clubs, golf elubs, industrial welfare clubs, sports associations, public authorities and education committees. Management of the Institute is in the hands of a Board of Management which includes representatives of tho main sports controlling bodies, namely, the English Golf Union, Scottish Golf Union, Golfing Union of Ireland, Welsh Golfing Union, Football Association, Football Leaguc, Ltd., Lawn Tennis Association, Rugby Football Union., Rugby Football League and the English Bowling Association. 'The Board has avsilable both scientific and practical advisory committees for consultation. In pursuance of its object, the Institute has a comprehensive research programme for investigating problems of general turf management, problems of individual management of turf for particular purposes and, of course, the control of weeds, pests and diseases. Extensive field trials running to many hundreds of plots are backed by useful laboratory facilities.

Field work at present in progress at the Research Station (and demonstrated on the open day) includes trials on height of cut, top-dressing materials, longterm fertilizer treatment, weed control, disease control, grass growth stunting and seeds mixtures. Although the main experimental ground bears a considerable number of trials, many experiments can only be carried out satisfactorily at outside centres; for example, at present a new series of simple trials on sceds mixtures for renovating football grounds is in progress. Turf diseases and their control are receiving particular attention at the moment, with attempts to produce cheaper and more efficient materials for controlling known turf diseases. It is interesting to note that this concentration on disease problems has revealed that one or two new diseases previously unrecognized occur quite frequently, and work is proceeding on methods of control.

IKnowledge gained from the various trials is passed on through the advisory work of the Institute, through instructional courses for groundsmen, greenkcepers and other interested persons and also through lectures given by members of the staff at various centres throughout Great Britain. In addition, an annual Journal is produced and also brief quarterly Bulletins, both these publications boing circulated to all affiliated members. The advisory services are being increasingly called upon, and more and more is being demanded of the staff concerned in this work.

The Institute was founded in 1929 by the golf clubs through the four national Unions; but the great expansion of activities, particularly since the Second World War, in various other directions, led to a reorganization and the formation of the Sports Turf Research Institute. The status of the organization as an independent non-profit-making scientific body was recognized by the granting of a licence from the Board of Trade in August 1951, thus permitting the Institute to be registered and to operate withont the use of the word 'Limited' in its title. The former Board of Greenkeeping Research ceased to exist on September 3, 1951. It has become increasingly obvious that the Institute has an important part to play in the future as in the past. More and more its advice is called upon in the construction of new playing fields for all kinds of bodies. In particular, the educational programme of producing more new school playing fields demands a great deal of attention from the Rescarch Station in order to enable the education authorities to produce fields of sufficient quality without unnecessary expenditure of public funds.

\section{DEVELOPMENT AND UTILIZA- TION OF WATER RESOURCES}

$T$

HE eightecnth sossion of the United Nations Economic and Social Council, which opened in Geneva on June 29, discussed among other items a report on the Development and Utilization of Water Rosources*. This report was prepared as a result of earlier resolutions calling for information on the work being done by the specialized agencies and

- United Nations: Economic and Sncial Council. Report on the Development and Utilization of Water Resources. Pp. 20. (Iondon: United Nations-London Information Centre, 1954.) 